\title{
Factors Affecting Undergraduate Entrepreneurial Intention: The Effect of Entrepreneurial Education, Previous Experience, and Personal Skills
}

\author{
K.L.N.K. Gunathunge ${ }^{1}$ \\ Department of Commerce and Financial Management \\ University of Kelaniya \\ Kelaniya \\ SRI LANKA \\ nipunaka_2019@kln.ac.lk ${ }^{1}$
}

\begin{abstract}
It is generally accepted that entrepreneurship can be taught and that learning leads to new venture creation. However, some argue that entrepreneurship cannot be taught. With this in mind, this study examined the relationship of entrepreneurial education, personal skills, and previous experience to examine which factor plays the most effective role in making an impact on the intention to become an entrepreneur. The study sample consisted of 218 management undergraduates from three leading universities in Sri Lanka and data were collected through the administration of a formal questionnaire. Generally, the overall results of the study indicate that the best way to make an impact on undergraduates is to guide them through practical entrepreneurial experience rather than focusing more on formal theoretical knowledge.
\end{abstract}

Therefore, this study suggests academics, to integrate the more practical experience into the entrepreneurship course curriculums and this will reshape the future development of the entrepreneurial education field.

Keywords-: Entrepreneurial Education, Entrepreneurial Intention, Personal Skills, Previous Experience

\section{INTRODUCTION}

Entrepreneurs play a key role in any country and are positively affected by the new and innovative business startups (Kiss, Danis \& Cavusgil, 2012). Defining the term 'entrepreneur' and setting up the boundaries of the field of entrepreneurship was a problem that exists and continues to remain (Cunningham \& Lischeron, 1991; Bruyat \& Julien, 2001). However, entrepreneurs can be identified as people who have the right set of skills and great initiative that necessary to 
take viable new ideas to market; and to make the right decisions that lead to profitability (Arunachalam et al., 2018). In the past two decades, it has become more and more evident that entrepreneurs have a strong influence on the widening of employment opportunities, productivity, and the level of innovation in an economy (Audretsch, 1998). Especially in Sri Lanka, as a developing nation; we need more entrepreneurs who are competent to perceive new opportunities and convert them into viable business ventures. Therefore, it is better to find ways to create and develop new entrepreneurs by strengthening their vision.

In this study, the focus has been placed on the role that entrepreneurial education plays within entrepreneurship and how the other constructs behave when deciding to become an entrepreneur. On the contrary, there are a lot of factors that affect the decision of becoming an entrepreneur (Talebi, Nouri \& Kafeshani, 2014; Wajeeh Elali Badriah Al-Yacoub, 2016). Among them, entrepreneurial education, personal skills, and previous experience are considered as the main constructs of the study.

For instance, social participation of humans begins in early childhood; where children first engaged with their parents; and this engagement contributes to learning from experience. (Brown, Collins \& Duguid, 1989; Rogoff, 1990; Lent \&
Brown, 1996). Likewise, people engage with surrounding communities and gain the required knowledge, and utilize them to build sustainable business ventures. And this will also contribute to the development of personal skills as well. In this regard, the researcher has identified personal skills and previous experience as forms of social participation (Liñán, 2008; Politis, 2008). Moreover, according to Kolb (2015), learning from experience or rather 'Experiential learning' is identified as an effective way of learning in any setting.

However, the literature on experiential learning of entrepreneurs is not sufficient enough and needs to develop more insights on this to identify the relationship between these two elements (Wang \& Chugh, 2014; Nenzhelele, Moraka \& More, 2016). And even experiential learning can be used as a tool to encourage entrepreneurship education as well (Dhliwayo, 2008).

When compared to previous experience and personal skills; entrepreneurship education is a formal way of learning that delivering people with knowledge, skills, and motivation to stimulate entrepreneurial intention and success (Cho, 1998). Though scholars Martin, Mcnally \& Kay (2013) affirm that the existing pieces of evidence are not sufficient enough to express the importance of entrepreneurship education in creating better 
entrepreneurs. The author further discussed that the existing literature in the field indicated both the negative and positive impact of entrepreneurial education on intention.

\section{Problem}

In the given context, the unemployment level around the globe is rising to a peak. According to the global Employment Trends for Youth 2020 (GET youth 2020), the unemployment level (Age between $15-24)$ is rising rapidly when compared to the 2018 figures. In the Asian region, they have estimated around $14 \%$ youth unemployment level, which is exceeding the global unemployment level of $13.7 \%$. On the other hand, young people who are currently employed face greater risk due to the implementation of new technologies and automation of job roles. However, those who have higher education are less likely to lose their jobs. But with the current trend, they have also faced the same issue due to the increasing number of youths with higher-level education which threatens to outpace the demand for graduate labor and this will push down the graduate wages as well.

Furthermore, globalization, the world financial crisis, and the adaption of new technologies makes economies more vulnerable and create limitations. With these limitations' businesses are unable to provide or create new job opportunities for the youth, to fulfill the current demand, and to provide support for economic growth. Thus, in this scenario, Entrepreneurship can be proved as a solution to adapt to the changing economy and to solve other economic problems such as unemployment among youths.

Therefore, the researcher has identified the importance of producing more young entrepreneurs for the market, Hence, it will create more opportunities in the market place to boost the economic activities and to reduce the unemployment level of youths in the country. Therefore, the researcher is interested in the question of "How to create entrepreneurs?", "what are the facts that influence a person to become an entrepreneur?". By reviewing past literature on entrepreneurship, the researcher has identified some factors that influence a person to become an entrepreneur. Some become entrepreneurs through cognitive learning while others become entrepreneurs through social participation.

Therefore, the paper is grounded primarily in the debate surrounding the question of, do undergraduates find entrepreneurial education as resourceful or do the previous experience and personal skills support when becoming an entrepreneur. Therefore, this study will be carried out to discover and understand which factor plays the most effective role in 
making an impact on the intention to become an entrepreneur.

The study intends to achieve the following objectives; (a) to identify the impact of entrepreneurial learning from formal education on entrepreneurial intention. (b) to identify the impact of personal skills on entrepreneurial intention. (c) to identify the impact of previous experience on entrepreneurial intention.

\subsection{Literature Review}

\subsubsection{Entrepreneurship}

Creating new business ventures is important for job creation and new market creation and it positively affects economic development as well (Nishantha, 2009). Most importantly, there is no universal definition of entrepreneurship (Cunningham \& Lischeron, 1991; Bruyat \& Julien, 2001; Iversen, Jørgensen \& Malchow-Møller, 2008). However, scholars' view of entrepreneurship has changed significantly since Schumpeter defined the term in 1934 for the first time. According to Drucker (1985), entrepreneurship is an "...innovative act, which includes endowing existing resources for new wealth-producing capacity." In the view of Drucker (1985), entrepreneurship is the creation of a new organization, regardless of its ability to sustain itself, let alone make a profit.

Though the definitions presented by scholars seem to be somewhat simplistic, it describes the nature of entrepreneurial activities with risktaking and the bearing of uncertainty by the individual (Swoboda, 1983). Gartner (1985) simply outlined the term, entrepreneurship as the "creation of a new organization." However, according to Carrier (1996), entrepreneurship is also can be considered as a primary source of innovation and it may involve the development of new visions and business methods for the creation and establishment of new organizations.

\subsubsection{Entrepreneur}

In the early 1700's, The French economist, Richard Cantillon, defined an entrepreneur, as one who assumes risks by buy at a certain price and selling at uncertain prices, the difference between that is the profit or loss bear by the individual (Barreto, 1989; Casson, 1982; Bordo \& Murphy, 1989). Further, Morrison (1999) identified and list down a set of talents that an entrepreneur has posses; according to the researcher, an entrepreneur; is one who: intelligent and analytical, effective risk manager and a networker, possesses a strong set of moral, social, and business ethics exhibits a basic trader's instinct and dedicated to life-long learning in many forms. The talents mentioned here are vital for becoming successful entrepreneurs in the knowledge era. Other than the talents, 
Lee and Peterson (2000) highlighted the significance of a national culture that supports entrepreneurial activities. According to the researcher, even those individuals who are inspired by elements such as financial rewards, achievement, social, career, and individual fulfillment need a supportive culture. Watson, Hogarth-Scott, and Wilson (1998) and Morrison (1999) studies also claim that entrepreneurial spirit needs a suitable social and cultural environment to initiate motives for venture creation and aspiration for excellence in various academic areas to create a successful business venture.

\subsubsection{Entrepreneur and Work}

Cognition and motivation approaches can be used when studying the entrepreneur behavior (Shaver \& Scott, 1991). The entrepreneurship intention approach is the latest approach used by several researchers to understand the entrepreneurial process and behavior and it provides strong statistical support for understanding the behavior of an entrepreneur (Mull, 2012; Ozaralli \& Rivenburgh, 2016). Entrepreneurial intention is vital for potential entrepreneurs because, simply the intentions demonstrate the future behavior of an entrepreneur and why they are intending to start their venture before the opportunity search (Mcstay, 2008; Ajzen, 1991; Krueger, Reilly \& Carsrud, 2000). Becoming an entrepreneur is a summation of entrepreneurship and the entrepreneurship process (Maharani, 2014). Most of the researchers have studied the entrepreneur as an individual party (Bruyat \& Julien, 2001).

\subsubsection{Entrepreneurship Education}

Some different definitions and theories exist to define the term 'learning'. Therefore, it believes that there is no universal definition to define the term (West, 2018). In general, there are five main learning theories (social constructivism, social cognitive, cognitivism, humanism, and behaviorism), and scholars utilized those theories to identify how to incorporate and apply them into entrepreneurship learning (Toutain and Byrne, 2012). However, when it comes to discussing the concept of 'entrepreneurial' learning this resonates well with the overall discussion of several studies that talk about the learning modes of individuals (Bandura, 1986; Young \& Sexton, 1997; Deakins \& Freel, 1998).

According to many scholars who have studied the area of the "impact of Entrepreneurship Education" highlights the importance of Entrepreneurship Education (Gorman, Hanlon \& King, 1997; Lee, Chang \& Lim, 2005; Fayolle, Gailly \& LassasClerc, 2006). The majority of the 
scholars' studies in the area of Entrepreneurship Education suggest that Entrepreneurship is a teachable discipline (Lange et al., 2014; Popescu, 2016). However, the entrepreneurship education programs should adjust accordingly based on target clientele and evaluations because students' attitudes towards entrepreneurship can be changed over time (Bechared and Toulouse 1998). According to Mcstay (2008), the most suitable way of evaluating entrepreneurship courses is to evaluate the attitude changes of the participants about entrepreneurship and the impact of these on their entrepreneurial intentions.

Ducker (1985) also states that entrepreneurship is a behavioral pattern and entrepreneurship courses sharpen the individuals' attitudes and they learn how to behave entrepreneurially. Further studies about entrepreneurship education mainly focus on enterprise education and consider course content, teaching methods, entrepreneurial learning, and assessment (Greene \& Rice, 2007). However, a broad range of entrepreneurship training programs are offered worldwide and given the diversity of such programs, measurement and comparison of their effectiveness are problematic; therefore, researchers emphasize the need to evaluate the effectiveness of entrepreneurship programs (Walter \& Block, 2016; Porter \& McKibbin, 1988). Garavan and O'Cinneide
(1994) also present an analysis of six European entrepreneurship programs concluding with a call for an increased evaluation of the effectiveness of programs worldwide. Bechard and Toulouse (1998) suggest the goal of entrepreneurship education training programs should be specific to the target client and in turn, evaluation should be adjusted accordingly.

\subsubsection{Previous Experience}

During this research, the researcher would be following the relationship between the practical entrepreneurial experiences in relating to working as an entrepreneur or engaged in someone's venture. According to Mcstay (2008), practical entrepreneurial experience means prior knowledge with the identification of a greater number of more innovative entrepreneurial opportunities. Prior knowledge is defined as an individual's distinctive information about a specific subject matter and may be the result of previously attained work experience or education (Hailikari, Katajavuori \& Lindblom-Ylanne, 2008). Adapting Social Cognitive Theory (Bandura, 1986) from a social learning perspective, occupational role models and previous experience are important environmental factors in an individual's career selection process. It is a function of knowledge and it is reasonable to assume that participation in entrepreneurship 
education and previous entrepreneurial experience would increase an individual's entrepreneurial knowledge. Previous relevant entrepreneurial experience and knowledge may be likely candidates to engage in Entrepreneurial behavior at some stage in their life cycle.

Reitan (1997) also found that Practical business experience strongly influenced the intention to become an entrepreneur. Scherer et al. (1989) stated that different learning histories and experiences may distinguish an entrepreneur from a nonentrepreneur.

\subsubsection{Intention to Start a Business}

This study is mainly focused on the study of the self-employment intention of Sri Lankan undergraduates. The entrepreneurship education programs which are offer for university undergraduates can positively impact their entrepreneurial intention and make a positive attitude about entrepreneurship. Practical studies show that entrepreneurship education is an important internal factor in the entrepreneurial intention model as well (Krueger, 1993).

The purpose of studying intention is to predict the behavior of a particular person or group and cognitive psychologists have studied this area for many years, in which writers including Assagioli, 1973; James, 1950; Lewin, 1935; Rotter, 1966.
According to Krueger and Brazeal (1994), Entrepreneurial intention can be defined as a person's intention to a particular entrepreneurial behavior. Crant (1996) described selfemployment intention as an individual's wish to run their own business. Lee and Wong (2004) stated that the first step of the new organizational emergence is selfemployment intention. Furthermore, Bird (1988) Mentioned that new ventures consist of an entrepreneur's intention and subsequent actions. In his model thinking style, personal history, ability, and environmental states are the intentional actions of an entrepreneur.

Finally, the hypotheses of the study can be derived as follows.

\section{Hypotheses}

H1: There is a significant impact of Formal Entrepreneurial Education on Intention for Entrepreneurship.

H2: There is a significant impact of Personal Skills on Intention for Entrepreneurship.

H3: There is a significant impact of Previous Entrepreneurial Experience on Intention for Entrepreneurship.

\section{METHODS}

As mentioned above, the goal of this research is to study and deepen the knowledge of the relationships between entrepreneurial learning and the intention of entrepreneurship. To fulfill the objective of the research, 
the researcher did collect and analyze the data using quantitative approaches. Hence the research design would be a survey study.

The questionnaire was prepared including both open and closed (mixed Model) questions (used five Likert scale method) which are relevant to measure the objectives of the research. And also, the questionnaire was designed and presented with simple wordings and this will make it easy to understand for the respondents. A convenient sampling method was used to gather data from the sample. The sample will consist of 218 undergraduates in the relevant stream who are currently reading for their degree in three universities. The rationale behind the choice of the three universities was to obtain samples from the universities in Western Province. A descriptive analysis is conducted to examine the nature of the sample and to obtain summarized statistics. And the correlation analysis was conducted to detect the relationships between the independent variables and the dependent variable. Further, a multiple regression analysis was carried out to analyze the impact of entrepreneurial education, personal skills, and previous experience on Entrepreneurial Intention. Both the analysis were conducted utilizing SPSS Software (Statistical Package for Social Science).

\section{RESULTS}

As per the respondent's statistics, from 218 respondents - there were almost equal proportions of male and female students, with a slight majority of female students of $52 \%$. All the respondents are from three state universities, Jayawardhanapura, Colombo, and Kelaniya and all of them are studying entrepreneurship. Demographic variables will be useful to identify their behaviour when interpreting the collected data.

Before proceeding further into the analysis, this research conducted the following test in accordance to test the reliability of the questions. The reliability of the instruments used in this research was tested using SPSS. All values in the inter-item correlation matrices were positive values, indicating that the items are measuring the same underlying characteristic and confirming the internal consistency of the scales. Cronbach alphas are presented in Table 1 below and suggest a strong relationship amongst the items on each scale for each variable.

Table 1: Reliability analysis

\begin{tabular}{|l|c|}
\hline \multicolumn{1}{|c|}{ Construct } & Cronbach's Alpha \\
\hline $\begin{array}{l}\text { Formal } \\
\text { Entrepreneurship } \\
\text { Education }\end{array}$ & .721 \\
\hline Personal Skills & .824 \\
\hline Personal Experience & .850 \\
\hline
\end{tabular}




\begin{tabular}{|l|c|}
\hline $\begin{array}{l}\text { Entrepreneurial } \\
\text { Intention }\end{array}$ & .789 \\
\hline
\end{tabular}

Source: Generated by Author using SPSS

According to the test, results relating to formal entrepreneurship education, personal skills, personal experience, and entrepreneurial intention are .721, $.824, .850$, and .789 , respectively. According to the rule of thumb, the above results are in a good range (George \& Mallery, 2003).
Thereafter, the validity of the data set measured using KMO and Bartlett's Test (Table 2). And results of the test indicate that factor analysis may be useful with provided data. The Kaiser-Meyer-Olkin measure of sampling adequacy is $>0.50$ and Bartlett's Test Sphericity significance level is $<0.05$.

\section{Table 2: KMO and Bartlett's Test}

\begin{tabular}{|l|r|}
\hline Kaiser-Meyer-Olkin Measure of Sampling Adequacy. & .651 \\
Bartlett's Test of & 3009.088 \\
\cline { 2 - 2 } Sphericity & 190 \\
\cline { 2 - 2 } & .000 \\
\hline
\end{tabular}

Source: Generated by Author using SPSS.

Before testing the hypotheses, the conducted to identify the relationship Pearson correlation (Table 3) test was between IVs \& DV.

Table 3: correlation

\begin{tabular}{|l|l|r|}
\hline \multicolumn{2}{|c|}{ Formal } \\
Entrepreneurship & Pearson Correlation & Intention for Entrepreneurship \\
Education & Sig. (2-tailed) & $.507^{* *}$ \\
& $\mathrm{~N}$ & .000 \\
\hline Personal Skills & Pearson Correlation & 218 \\
& Sig. (2-tailed) & $.435^{* *}$ \\
& $\mathrm{~N}$ & .000 \\
Previous & Pearson Correlation & 218 \\
Extrepreneurial & Sig. (2-tailed) & $.632^{* *}$ \\
& $\mathrm{~N}$ & .000 \\
& & 218 \\
\hline
\end{tabular}

**. Correlation is significant at the 0.01 level (2-tailed).

Source: Generated by Author using SPSS 
According to the results derived from the test, the Pearson Correlation values between IVs and DV are positive. There is a moderate positive relationship between formal entrepreneurship education, personal skills, and intention for entrepreneurship. And also results indicate, a strong positive relationship between previous entrepreneurial experience and intention for entrepreneurship.

Table 4: Model summary

\begin{tabular}{|l|c|c|c|c|c|}
\hline Model & $\mathbf{R}$ & $\mathbf{R}^{\mathbf{2}}$ & Adjusted $\mathbf{R}^{\mathbf{2}}$ & $\begin{array}{c}\text { Std. Error of the } \\
\text { Estimate }\end{array}$ & Durbin-Watson \\
\hline 1 & $.676^{\mathrm{a}}$ & .457 & .449 & .47122 & 1.363 \\
\hline
\end{tabular}

a.Predictors: (Constant), Previous Entrepreneurial Experience, Personal Skills, Formal Entrepreneurship Education

b.Dependent Variable: Intention for Entrepreneurship

Source: Generated by Author using SPS

Table 5: ANOVA table in the regression analysis

\begin{tabular}{|l|c|c|c|c|c|}
\hline \multicolumn{1}{|c|}{ Model } & $\begin{array}{c}\text { Sum of } \\
\text { Squares }\end{array}$ & Df & Mean Square & F & Sig. \\
\hline Regression & 39.954 & 3 & 13.318 & 59.98 & $.000^{\mathrm{b}}$ \\
\hline Residual & 47.518 & 214 & .222 & & \\
\hline Total & 87.472 & 217 & & & \\
\hline
\end{tabular}

a.Dependent Variable: Intention for Entrepreneurship

b.Predictors: (Constant), Previous Entrepreneurial Experience, Personal Skills, Formal Entrepreneurship Education

Source: Generated by Author using SPSS

Table 6: Coefficient table for the regression analysis

\begin{tabular}{|c|c|c|c|c|c|}
\hline \multirow{2}{*}{ Model } & \multicolumn{2}{|c|}{$\begin{array}{c}\text { Unstandardized } \\
\text { Coefficients }\end{array}$} & $\begin{array}{c}\text { Standardized } \\
\text { Coefficients }\end{array}$ & T & Sig. \\
\hline & B & SD & Beta & & \\
\hline (Constant) & .635 & .145 & & 4.397 & .000 \\
\hline FE & .121 & .073 & .111 & 1.648 & .101 \\
\hline
\end{tabular}




\begin{tabular}{|c|c|c|c|c|c|}
\hline PS & .146 & .041 & .207 & 3.591 & .000 \\
\hline PE & .393 & .051 & .491 & 7.720 & .000 \\
\hline
\end{tabular}

a. Dependent Variable: Intention for Entrepreneurship

Source: Generated by Author using SPSS

The model summary (Table 4) indicates the Multiple Linear Regression results of the analysis. It depicts the impact of the independent variables on the dependent variable. As per the results, the R Square value indicates a high level $(45.7 \%)$ of model fit and the Adjusted R square value confirmed $44.9 \%$ of the impact. And the overall model fit is significant

under the 0.05 level of significance level. Finally, it can conclude that the

Table 7: Results of hypothesis testing personal skills and previous entrepreneurial experience are statistically significant when predicting the intention for entrepreneurship (DV) of the study. However, in this case, formal entrepreneurial education is not significant under the 0.05 level of significance.

\section{Hypothesis Testing}

Results derived from the data analysis can be illustrated as follows.

\begin{tabular}{|l|l|c|}
\hline $\mathbf{H}_{\mathbf{1}}$ & $\begin{array}{l}\text { Hypothesis } \\
\text { There is a significant impact of Formal } \\
\text { Entrepreneurial Education on Intention } \\
\text { for Entrepreneurship. }\end{array}$ & Rejult \\
\hline $\mathbf{H}_{\mathbf{2}}$ & $\begin{array}{l}\text { There is a significant impact of Personal } \\
\text { Skills on Intention for Entrepreneurship. }\end{array}$ & Accepted \\
\hline $\mathbf{H}_{3}$ & $\begin{array}{l}\text { There is a significant impact of Previous } \\
\text { Entrepreneurial Experience on Intention } \\
\text { for Entrepreneurship. }\end{array}$ & Accepted \\
\hline
\end{tabular}

\section{DISCUSSION}

This study is subject to some limitations. The sample is limited to three universities in the western province of Sri Lanka and university undergraduates who study entrepreneurship as a course unit. However, the author believes that the limitations can be eliminated with further studies. Meanwhile, the results of the study revealed that the impact of entrepreneurship education is less or rather not significant when

compared to previous entrepreneurial experience and personal skills on the entrepreneurial intention of the undergraduates. Past literature on entrepreneurship teaching and 
learning methods commended the results derived from the current study. Authors, Davies and Gibb (1991) explained how critical the adoption of traditional education methods, that mainly focus on theoretical approaches. According to the authors, those methods are inappropriate in the teaching of entrepreneurship. Young (1997) affirms this view and suggests that the practical skills and experience used by entrepreneurs cannot be gained or acquired through these traditional teaching and learning methods. Further Gibb (1987) suggests a flexible and active experience-based learning approach to teach entrepreneurship. According to the findings of Timmons and Stevenson (1985), the best way to learn entrepreneurship is to combine experience with formal educational activities. The authors further discuss that entrepreneurship is a field that can be taught but there are some critical skills that entrepreneurs need to learn. However, to learn those critical skills, such as judgment, patience, responsibilities, and handling people; entrepreneurs need to engage with the real world and gained experience from there. Moreover, the research findings of Kirby (2004) revealed that all the entrepreneurial characteristics can be developed within a student, but not using the traditional teaching methods and traditional standard functional competences that are used in business schools.
In the current context, entrepreneurship educational programs merely produce entrepreneurship graduates. Because, teaching undergraduates how to write a good business plan is not enough to become an entrepreneur (Rauch, Potishuk \& Kratzer, 2018). Moreover, the curricula of these entrepreneurship programs follow traditional theoretical teaching methods. Higher education institutes, such as public and private universities, have an important role in the supply of quality and welleducated graduates as entrepreneurs (Rae, 2004). To affirm this argument; there is a general agreement between researchers that traditional teaching methods in entrepreneurship are not sufficient enough to develop quality entrepreneurs to run and create business ventures with high complexities (Higgins, Smith \& Mirza, 2013).

Because in the era of globalization, with rapidly changing technology, markets, and economies; entrepreneurs need to deal with a high level of uncertainties along with risks (Wang, 2019). Therefore, this study suggests educational institutions and academics to explore and identify the following areas before they deliver the program content to the student. How does (a) the type of teaching method, (b) the background of lecturers, (c) the entrepreneurial intention of lecturers, (d) and the contents of entrepreneurship 
education programs affect students' intentions? (Theoretical and practical knowledge).

Authors Higgins and Elliott (2011) presented experiential methods of learning as a new era of entrepreneurial education. Where undergraduates can learn with more practical related scenarios rather than based on traditional theoretical methods of learning. Even authors, Neck and Greene (2011) suggest, the importance of applying theoretical knowledge gained by students to realworld scenarios and learn from the experience. Thereby, undergraduates will get an opportunity to put the learned theories into practice and actively engaged in business opportunity exploitation and understand the real challenges of running a business venture (Sarasvathy, 2001).

Therewith, authors tend to highlight the importance of teaching practical entrepreneurship to undergraduates (Peters et al., 2014; Nenzhelele, Moraka \& More, 2016). This argument can be equated to the teaching and learning methods of doctors. Simply doctors cannot proceed with surgeries without having practical experience. The results of the study may have valuable implications for policymakers, academics, and educators. The author of this study would like to suggest academics and educators to compile an extensive curriculum for entrepreneurship education programs by integrating modules to develop undergraduates' experiences in practical businesses and modules to develop their skills and also, there is a need for more innovative and radical approaches to teach and learn entrepreneurship than appears to have been evident to date.

\section{CONCLUSION}

This article intended to explore the effect of entrepreneurship education, previous experience, and personal skills on the entrepreneurship intention of Sri Lankan university undergraduates. The results of the study found that only two variables of the model were significant. The first factor is previous experience and the second factor is the personal skills of undergraduates. Moreover, this study was limited to undergraduate studies in three major universities in Sri Lanka. The number of students who participated in this study was also limited to 218 students. Therefore, the author recommends conducting more research on this, since, it is not possible to ignore the contribution of formal entrepreneurial education programs in creating quality entrepreneurs. Finally, future research should focus more on to evaluate progress in formal entrepreneurship education and to bridge the knowledge gap of how other aspects that affect entrepreneurial intention interacts with formal entrepreneurial education. 


\section{REFERENCES}

Ajzen, I. (1991) 'The theory of planned behavior', Organizational Behavior and Human Decision Processes, 50, pp. 179-211.

Arunachalam, S. et al. (2018) 'Innovation pathway to profitability: the role of entrepreneurial orientation and marketing capabilities', Journal of the Academy of Marketing Science. Journal of the Academy of Marketing Science, 46(4), pp. 744-766.

Assagioli, R. (1973)'The act of will'. New York: Penguin

Audretsch, D. B. (1998) 'Agglomeration and the location of innovative activity', Oxford Review of Economic Policy, 14(2), pp. 18-29.

Bandura, A. (1986) 'The Explanatory and Predictive Scope of SelfEfficacy Theory', Journal of Social and Clinical Psychology, 4(3), pp. 359-373.

Barreto, H. (1989), 'The Entrepreneur in Economic Theory, Disappearance and Explanation.'London:

Routledge.

Bechard, J. P., and Toulouse, J. M. (1998) 'Validation of a didactic model for the analysis of training objectives in entrepreneurship', Journal of Business Venturing, 13(4), pp. 317-332.
Bird, B. (1988) 'Implementing Entrepreneurial Ideas: The Case for Intention', Academy of Management Review, 13(3), pp. 442-453.

Bordo, M. D., and Murphy, A. E. (1989) Richard Cantillon: Entrepreneur and Economist., The Economic History Review.

Brown, J. S., Collins, A. and Duguid, P. (1989) 'Situated cognition and the culture of learning', Educational Researcher, pp. 288-305.

Bruyat, C. and Julien, P. A. (2001) 'Defining the field of research in entrepreneurship', Journal of Business Venturing, 16(2), pp. 165-180.

Carrier, C. (1996) 'Intrapreneurship in Small Businesses: An Exploratory Study', Entrepreneurship Theory and Practice, 21(1), pp. 5-20.

Casson, M. C. (1982) 'The Entrepreneur: An Economic Theory. 'University of Illinois at Urbana-Champaign's Academy for Entrepreneurial Leadership Historical Research Reference in Entrepreneurship.

Cho, B. (1998). 'Study of the effective entrepreneurship education method and its process.'Business Education Research, 2(1):27-47.

Crant, J. M. (1996) 'The proactive personality scale as a predictor of entrepreneurial intentions', 
Journal of Small Business Management, 34(3), pp. 42-49.

Cunningham, J. B., Lischeron, J. (1991) 'Defining entrepreneurship', Journal of small business management, 29(1), pp. 45-61.

Davies, L.G., and Gibb, A.A. eds., (1991). Recent research in entrepreneurship. Aldershot: Avebury.

Deakins, D. and Freel, M. (1998) 'Deakins1998', The Learning Organization, 5(3), pp. 144155.

Dhliwayo, S. (2008) 'Experiential learning in entrepreneurship education: A prospective model for South African tertiary institutions', Education and Training, 50(4), pp. 329340.

Drucker, P. F. (1985) Innovation and Entrepreneurship Practice and Principles. HarperCollins Publishers.

Fayolle, A., Gailly, B. and LassasClerc, N. (2006) 'Assessing the impact of entrepreneurship education programmes: A new methodology', Journal of European Industrial Training, 30(9), pp. 701-720.

Garavan, T. N. and O'Cinneide, B. (1994) 'Entrepreneurship Education and Training Programmes: A Review and Evaluation Part 2', Journal of European Industrial Training, 18(11), pp. 13-21.
Gartner, W. B. (1985) 'A conceptual framework for describing the phenomenon of New Venture Creation', Entrepreneurship As Organizing: Selected Papers of William B. Gartner, 10(4), pp. $1-11$.

George, D., \& Mallery, P. (2003). SPSS for windows step by step: A simple guide and reference. 11.0 update (4th ed.). Boston: Allyn \& Bacon.

Gibb, A.A., (1987). Enterprise culture-It's meaning and implication for education and training. Journal of European Industrial Training Vol II No. 2.

Gorman, G., Hanlon, D., and King, W., (1997). Some research perspectives on entrepreneurship education, enterprise education, and education for small business management: a ten-year literature review. International small business journal, 15(3), pp.56-77.

Greene, P.G., and M. P. Rice (Eds.). (2007). 'Entrepreneurship Education.'Cheltenham, UK: Edward Elgar Publishing.

Hailikari, T., Katajavuori, N. and Lindblom-Ylanne, S. (2008) 'The relevance of prior knowledge in learning and instructional design', American Journal of Pharmaceutical Education, 72(5).

Higgins, D. and Elliott, C. (2011) 'Learning to make sense: What 
works in entrepreneurial education?', Journal of European Industrial Training, 35(4), pp. 345-367.

Higgins, D., Smith, K., and Mirza, M. (2013) 'Entrepreneurial Education: Reflexive Approaches to Entrepreneurial Learning in Practice', Journal of Entrepreneurship, 22(2), pp. 135-160.

Iversen, J., Jørgensen, R. and Malchow-Møller, N. (2008) 'Defining and Measuring Entrepreneurship',

Foundations and Trends in Entrepreneurship, 4(1), pp. 163.

James, W. (1950). 'The principles of psychology'. [New York], Dover Publications.

Kirby,

D.A.,

(2004).

Entrepreneurship education: can business schools meet the challenge?.

Education+ training.

Kiss, A. N., Danis, W. M. and Cavusgil, S. T. (2012) 'International entrepreneurship research in emerging economies: A critical review and research agenda', Journal of Business Venturing. Elsevier Inc., 27(2), pp. 266-290.

Kolb, D. A. (2015) Experiential Learning: Experience as the Source of Learning and Development, Experiential learning: Experience as the source of learning and development. Pearson
Education, Inc.

Krueger, N. (1993) 'The Impact of Prior Entrepreneurial Exposure on Perceptions of New Venture Feasibility and Desirability', Entrepreneurship Theory and Practice, 18(1), pp. 5-21.

Krueger, N. F., and Brazeal, D. V. (1994) 'Enterprise Potential and Potential Entrepreneurs', Entrepreneurship: Theory \& Practice, 18(3), pp. 91-104.

Krueger, N. F., Reilly, M. D. and Carsrud, A. L. (2000) 'Competing models of entrepreneurial intentions', Journal of Business Venturing, 15(5-6), pp. 411-432.

Lange, J. et al. (2014) 'Is Entrepreneurship a Teachable Profession? An Examination of the Effects of Entrepreneurship Education and Experience', SSRN Electronic Journal, (June 2012), pp. 1-22.

Lee, S. H., and Wong, P. K. (2004) 'An exploratory study of technopreneurial intentions: A career anchor perspective', Journal of Business Venturing, 19(1), pp. 7-28.

Lee, S. M., Chang, D., and Lim, S. (2005) 'Impact of Entrepreneurship Education: A Comparative Study of the U.S. and Korea', The International Entrepreneurship and Management Journal, 1(1), pp. 27-43.

Lee, S. M., and Peterson, S. J. (2000) 
'Culture, entrepreneurial orientation, and global competitiveness', Journal of World Business, 35(4), pp. 401-416.

Lent, R. W. and Brown, S. D. (1996) 'Social Cognitive Approach to Career Development: An Overview', Career Development Quarterly, 44(4), pp. 310-321.

Lewin, K. (1935). 'A dynamic theory of personality'. McGraw-Hill.

Liñán, F. (2008) 'Skill and value perceptions: How do they affect entrepreneurial intentions?', International Entrepreneurship and Management Journal, 4(3), pp. 257272.

\section{Maharani, D. (2014) "Entrepreneurship is a Magic Stick to Eliminate Poverty', International Research Journal of Agriculture and Rural Development, 3(1).}

Martin, B. C., Mcnally, J. J. and Kay, M. J. (2013) 'Journal of Business Venturing Examining the formation of human capital in entrepreneurship: A metaanalysis of entrepreneurship education outcomes', Journal of Business Venturing. Elsevier Inc., 28(2), pp. 211-224.

Mcstay, D. (2008) 'An investigation of undergraduate student selfemployment intention and the impact of entrepreneurship education and previous entrepreneurial experience Presented By', Behaviour.
Morrison, A. (1999)

'Entrepreneurship: what triggers it?', Int $J$ Logistics Management, 6(2), pp. 59-71.

Mull, V. (2012) 'An application of the psychological and behavioral approaches', Journal of Small Business and Enterprise Development, 19(3), pp. 424-440.

Neck, H.M., and Greene, P.G., (2011). Entrepreneurship education: known worlds and new frontiers. Journal of small business management, 49(1), pp.55-70.

Nenzhelele, T. E., Moraka, N. V. and More, K. K. (2016) 'The impact of practical entrepreneurship project on future entrepreneurial intentions', Problems and Perspectives in Management, 14(4), pp. 67-75.

Nishantha, B. (2009) 'Influence of Personality Traits and Sociodemographic Background of Undergraduate Students on Motivation for Entrepreneurial Career: The Case of Sri Lanka Influence of Personality Traits and Socio-demographic Background of Undergraduate Students on Motiv', (January), pp. 71-82.

Ozaralli, N. and Rivenburgh, N. K. (2016) 'Entrepreneurial intention: antecedents to entrepreneurial behavior in the U.S.A. and Turkey', Journal of Global Entrepreneurship Research. Journal of Global 
Entrepreneurship Research, 6(1).

Peters, R. M. et al. (2014) 'Education And Small Business Growth: A Gender Perspective Of Two Divergent Provinces In South Africa', International Business and Economics Research Journal, 13(5), pp. 1127-1140.

Politis, D. (2008) 'Does prior start-up experience matter for entrepreneurs' learning?: A comparison between novice and habitual entrepreneurs', Journal of Small Business and Enterprise Development, 15(3), pp. 472-489.

Popescu, T. (2016) 'IS ENTREPRENEURSHIP

Teachable? is

Entrepreneurship Teachable? Ioan Moise Achim Teodora Popescu', (November 2008).

Porter, L. W., \& McKibbin, L. E. (1988). 'Management education and development: Drift or thrust into the 21st century.'New York: McGraw Hill.

Rae, D. (2004) 'Entrepreneurial learning: A practical model from the creative industries', Education + Training, 46, pp. 492-500.

Reitan, B. (1997) 'Fostering technical entrepreneurship in research communities: Granting scholarships to would-be entrepreneurs', Technovation, 17(6), pp. 287-296.
Rogoff, B. (1990) Apprenticeship in Thinking: Cognitive Development in Social Context., OXFORD UNIVERSITY PRESS

Rotter， J. B. (1966). 'Generalized expectancies for internal versus external control of reinforcement. Psychological Monographs: General and Applied,' 80(1), 1-28.

Sarasvathy, S.D., (2001). Causation and effectuation: Toward a theoretical shift from economic inevitability to entrepreneurial contingency. Academy of Management Review, 26(2), pp.243-263.

Scherer, R. F. et al. (1989) 'Role Model Performance Effects on Development of Entrepreneurial Career Preference', Entrepreneurship Theory and Practice, 13(3), pp. 53-72.

Shaver, K. G., and Scott, L. R. (1991) 'Person, Process, Choice: The Psychology of New Venture Creation', Entrepreneurship Theory and Practice, 16(2), pp. 23-46.

Swoboda, Alexander K. (1983).'Exchange Rate Regimes and European-U.S. Policy Interdependence.' IMF Staff Papers 30, 75-102.

Talebi, K., Nouri, P. and Kafeshani, A. A. (2014) 'Identifying the main Individual Factors Influencing Entrepreneurial Decision making Biases: A 
Qualitative Content Analysis Approach', International Journal of Academic Research in Business and Social Sciences, 4(8), pp. 1-11.

Toutain, O. and Byrne, J. (2012) 'Learning theories in entrepreneurship: new perspectives', Academy of Management Conference, (December), pp. 1-36.

Wajeeh Elali Badriah Al-Yacoub (2016) 'Factors affecting entrepreneurial intentions among Kuwaitis', World Journal of Entrepreneurship, Management and Sustainable Development, 12(1), p. 21.

Walter, S. G., and Block, J. H. (2016) 'Outcomes of entrepreneurship education: An institutional perspective', Journal of Business Venturing. Elsevier Inc., 31(2), pp. 216-233.

Wang, C. L., and Chugh, H. (2014) 'Entrepreneurial learning: Past research and future challenges', International Journal of Management Reviews, 16(1), pp. 24-61.

Wang, T. (2019) 'Exploring the mode of entrepreneurship education based on the legal-business compound competency in China', Frontiers in Psychology, 10(MAY), pp. 111.

Watson, K., Hogarth-Scott, S. and Wilson, N. (1998) 'Small business start-ups: Success factors and support implications, International Journal of Entrepreneurial Behaviour \& Research, 4(3), pp. 217-238.

West, R. E. (2018) Foundations of Learning and Instructional Design Technology.

Young, J. E., and Sexton, D. L. (1997) 'Entrepreneurial Learning: a Conceptual Framework', Journal of Enterprising Culture, 05(03), pp. 223-248. 